\title{
Bioengineering beige adipose tissue therapeutics
}

\author{
Kevin M. Tharp ${ }^{1,2}$ and Andreas Stahl ${ }^{1 *}$ \\ ${ }^{1}$ Program in Metabolic Biology, Department of Nutritional Science and Toxicology, University of California Berkeley, Berkeley, \\ CA, USA, ${ }^{2}$ Department of Bioengineering, University of California Berkeley, Berkeley, CA, USA
}

Unlocking the therapeutic potential of brown/beige adipose tissue requires technological advancements that enable the controlled expansion of this uniquely thermogenic tissue. Transplantation of brown fat in small animal model systems has confirmed the expectation that brown fat expansion could possibly provide a novel therapeutic to combat obesity and related disorders. Expansion and/or stimulation of uncoupling protein-1 (UCP1)-positive adipose tissues have repeatedly demonstrated physiologically beneficial reductions in circulating glucose and lipids. The recent discovery that brown adipose tissue (BAT)-derived secreted factors positively alter whole body metabolism further expands potential benefits of brown or beige/brite adipose expansion. Unfortunately, there are no sources of transplantable BATs for human therapeutic purposes at this time. Recent developments in bioengineering, including novel hyaluronic acid-based hydrogels, have enabled non-immunogenic, functional tissue allografts that can be used to generate large quantities of UCP1-positive adipose tissue. These sophisticated tissue-

Edited by: Jun Wu,

University of Michigan, USA

Reviewed by:

Alexandros Vegiopoulos, German Cancer Research Center (DKFZ), Germany

Meilian Liu,

University of New Mexico Health Sciences Center, USA

*Correspondence: Andreas Stahl astahl@berkeley.edu

Specialty section: This article was submitted to Cellular Endocrinology, a section of the journal Frontiers in Endocrinology

Received: 01 September 2015 Accepted: 05 October 2015

Published: 20 October 2015

Citation:

Tharp KM and Stahl A (2015)

Bioengineering beige adipose tissue

therapeutics.

Front. Endocrinol. 6:164.

doi: 10.3389/fendo.2015.00164 engineering systems have provided the methodology to develop metabolically active brown or beige/brite adipose tissue implants with the potential to be used as a metabolic therapy. Unlike the pharmacological browning of white adipose depots, implantation of bioengineered UCP1-positive adipose tissues offers a spatially controlled therapeutic. Moving forward, new insights into the mechanisms by which extracellular cues govern stem-cell differentiation and progenitor cell recruitment may enable cell-free matrix implant approaches, which generate a niche sufficient to recruit white adipose tissue-derived stem cells and support their differentiation into functional beige/brite adipose tissues. This review summarizes clinically relevant discoveries in tissue-engineering and biology leading toward the recent development of biomaterial supported beige adipose tissue implants and their potential for the metabolic therapies.

Keywords: beige, adipose, brown fat, brown adipose, obesity, diabetes mellitus, bioengineering, hydrogel

\section{INTRODUCTION}

Proposing brown adipose tissue (BAT) expansion as a therapeutic treatment for obesity and obesityrelated disorders has recently gained significant traction $(1,2)$. BAT, as well as beige adipocytes (3, 4), has high metabolic capacity due to high mitochondrial content and expression of uncoupling protein-1 (UCP1) (5), a long-chain fatty acid anion/proton-symporter (6), found in the inner mitochondrial membrane. UCP1 decouples the action of ATP-synthase and dissipates the proton gradient produced by the electron transport chain, thus generating heat. BAT mass inversely 
correlates with body mass index (BMI), which supports the notion that BAT may regulate overall bodyweight and metabolic health (7). The benefits of expanded UCP1-expressing adipose may not be limited to their metabolic characteristics, as brown adipose has been shown to possess a potent secretome (8). Notably, implanted BAT has been shown to produce secretions of IGF-1, which was reported to enable the insulin-independent reversal of type-1 diabetes (9). BAT also appears to exert significant effects on the lipid metabolism in the liver $(10)$ and bone mineral density $(11,12)$. Overall, the generation of functional beige or brown adipocytes for therapeutic purposes appears to hold significant merit for a number of possible treatments.

The current strategies to clinically deploy BAT fall into two main categories: pharmaceutical or genetic interventions to induce endogenous BAT/beige differentiation pathways, and the ex vivo generation of autologous cell/tissue transplants (13-17). Current gene-therapy approaches still have challenges to overcome before they are applied as anti-obesity therapeutics (18), but have proven to be significant instruments for investigating BAT biology $(16,19)$. Pharmacological activation of the pathways that drive a white adipose tissue (WAT) to beige/brite transition, a process known as "browning", offer little control over the location and temporal extent of the effects. Transplantation of autologous BAT in small animal models has shown clear metabolic enhancements (20-22) but approaches are unlikely to be suitable for human therapies since there are few sources of transplantable mature human BAT and immune-rejection would need to be overcome. To successfully harness the therapeutic potential of BAT, a readily available source of transplantable cells with the potential to robustly generate UCP1-positive (UCP1+) adipocytes must first be identified or created. Second, the basis to form a functional, non-immunogenic, highly localized, and metabolically active brown/beige tissue must be defined.

\section{TISSUES FOR TISSUE-BASED THERAPIES}

The use of small molecules or growth factors to induce the browning of WAT is a promising area of research, but systemic dosing has the potential to produce off target effects with undesirable consequences. One notable browning agent, rosiglitazone, was widely used to treat diabetes but has disconcerting side effects that included heart failure (23). Browning factors (24-39) generally target conserved signaling pathways, making specificity a concern. By using biomaterials to localize and control release kinetics of browning factors to desired anatomical locations, an acceptable level of specificity may be achieved (40-46). When increasing the number of brown adipocytes, other supporting cell types are required for producing a functional tissue. For BAT, this includes interactions between the nervous, vascular, and immune systems, with UCP1+ adipocytes. Efforts to understand how brown or beige fat responds to cold temperature have uncovered evidence that classical brown fat relies on the sympathetic nervous system (47-49) and immune system $(50,51)$ to initiate and maintain the thermogenic response. While immune $(33,34)$ and nervous systems (52) also play a major role in beige fat development and activation, beige adipocytes have the innate ability to sense temperature and independently respond by either differentiating into UCP1+ adipose and/or by inducing uncoupled respiration
(53). Thus, classical brown, but not beige, tissue therapeutics will likely require sympathetic innervation for thermogenic function and persistence. The vascular system enables access to metabolic substrates, as well as the oxygen required for the metabolic activity of brown/beige fat (10). Additionally, vascular networks circulate activating or browning signals $(25,30,35,54-56)$. In addition to innervation and vascularization, tissue-based therapies facilitate important cell-cell and cell-extracellular matrix (ECM) interactions that provide function altering chemical and physical inputs (57-62).

Natural ECM is comprised of collagens, elastins, fibronectin, laminins, proteoglycans, and glycosaminoglycans (63). The ECM is a highly organized network of physical signals that dynamically interact with the cells it supports. The topology and composition of the ECM is heavily remodeled, especially during differentiation. Remodeling of the ECM is a balance of specific degradation by matrix metalloproteinases (MMPs), new matrix component deposition, unmasking of cryptic binding sites in response to cleavage or tension, crosslinking or bonding of ECM components, and inside-out signaling from adhesion receptors on cellular surfaces. Growth factor signaling is regulated through the ECM by controlling their capture or exclusion, rate of delivery to the cell surface receptor, and molecular presentation (64). The ECM establishes a biological framework that provides physical support to cells, but also regulates signaling through adhesion receptors and alters endocrine, paracrine, autocrine, and juxtacrine signals (62). To date, many groups have remade "synthetic" tissues by decellularizing the desired tissue, then reseeding the remaining native ECM with cell populations $(65,66)$. However, given the inaccessibility of mature BAT, this approach will be difficult to translate to artificial $\mathrm{UCP} 1+$ tissues.

Tissue architecture has been known to exert strong effects on cell behavior, and in vitro hydrogels, meant to mimic natural ECMs, appear to be a successful option to improve cell culture models (67). These 3-dimensional (3D) hydrogels, which are water swollen polymer networks, have been utilized to enhance hepatocyte (68) and pancreatic islet function (69). Not only does $3 \mathrm{D}$-organization affect the function and viability of cells (70), but it mediates the differentiation of many cell types (71), especially adipocytes. Adipogenesis is highly dependent on cytoskeletal rearrangements where cell shape is altered to accommodate the intracellular accumulation and organization of lipids. This was discovered when preadipocytes could not differentiate when cultured on a surface of fibronectin (72); this phenotype was rescued by disrupting the cytoskeletal response to the supraphysiological abundance of fibronectin. Laminin also has been found to play a role in WAT expansion (73). Another adipose ECM component, Collagen VI, was found to be an essential microenvironmental signal for adipocytes to regulate the amount of TAG they accumulate (74). When Collagen VI is removed from the adipose ECM, adipocytes develop a hypertrophic state in which the adipocytes are capable of sequestering significantly more lipids than normal. Specific ECM degradation is also a critical feature of WAT development (75). These phenomenal findings support the notion that the adipose ECM is an integral signal for adipocyte behavior and overall condition and function of the organ. When working with in vitro models of white adipocytes, it is also evident that the prototypical unilocular lipid 
droplets observed in vivo are not present unless cultured in 3Dmatrices $(76,77)$.

Comparatively little is known about the ECMs of WAT, BAT, and the changes in adipose-matrix during browning. As this area of research is explored further, ECM-derived signals will hopefully be identified to build our understanding of adipocyteECM interactions and provide applicable systems to induce the formation of UCP1+ adipocytes. Biomaterials have utilized the incorporation of whole ECM components, such as laminin (78) or collagen (79), to improve their biocompatibility and effectiveness as cell scaffolds. Whether or not specific mixtures of ECM components can be combined with preadipocytes to form functional brown fat has yet to be determined, but this approach has already been applied to WAT $(66,80,81)$. ECM molecules could theoretically be derived from the same tissues used to isolate the primary precursor cell populations for the generation of an adipose allograft (66) but thermogenic fat may have a distinct structural niche capable of engaging specific integrin (82) and syndecan (83) populations. Integrin expression is known to be highly dynamic during adipogenisis (84) and the beta-1 integrin has been extensively used to purify preadipocytes (85). Therefore, targeting integrin signaling appears to be a logical method to alter adipogenesis and it is likely that UCP1+ tissue function is dependent on specific $3 \mathrm{D}$ interactions and organization. This has now been demonstrated via integrin-ligands, in the form of matrix-derived peptide sequences and secreted molecules, on both UCP1-expression and lipid accumulation $(86,87)$.

\section{MATERIALS TO BUILD TISSUES}

Decellularized tissue-based tissue-engineering is not the only method to produce synthetic tissues $(81,88,89)$. Polymeric biomaterials with bioactive modifications have been employed to generate many tissue types $(61,90-92)$. Tissue-engineering is a sophisticated endeavor that requires significant tuning, therefore modular approaches should be considered for the construction of functional synthetic tissues. Specifically, the physical properties, degradation kinetics, and biologically interactive components should be able to be altered independently. Bioengineered tissues can be generated through the selection of a core polymer, a crosslinking system, bioactive modifications, and the incorporated cell populations (Figure 1). The core material of the

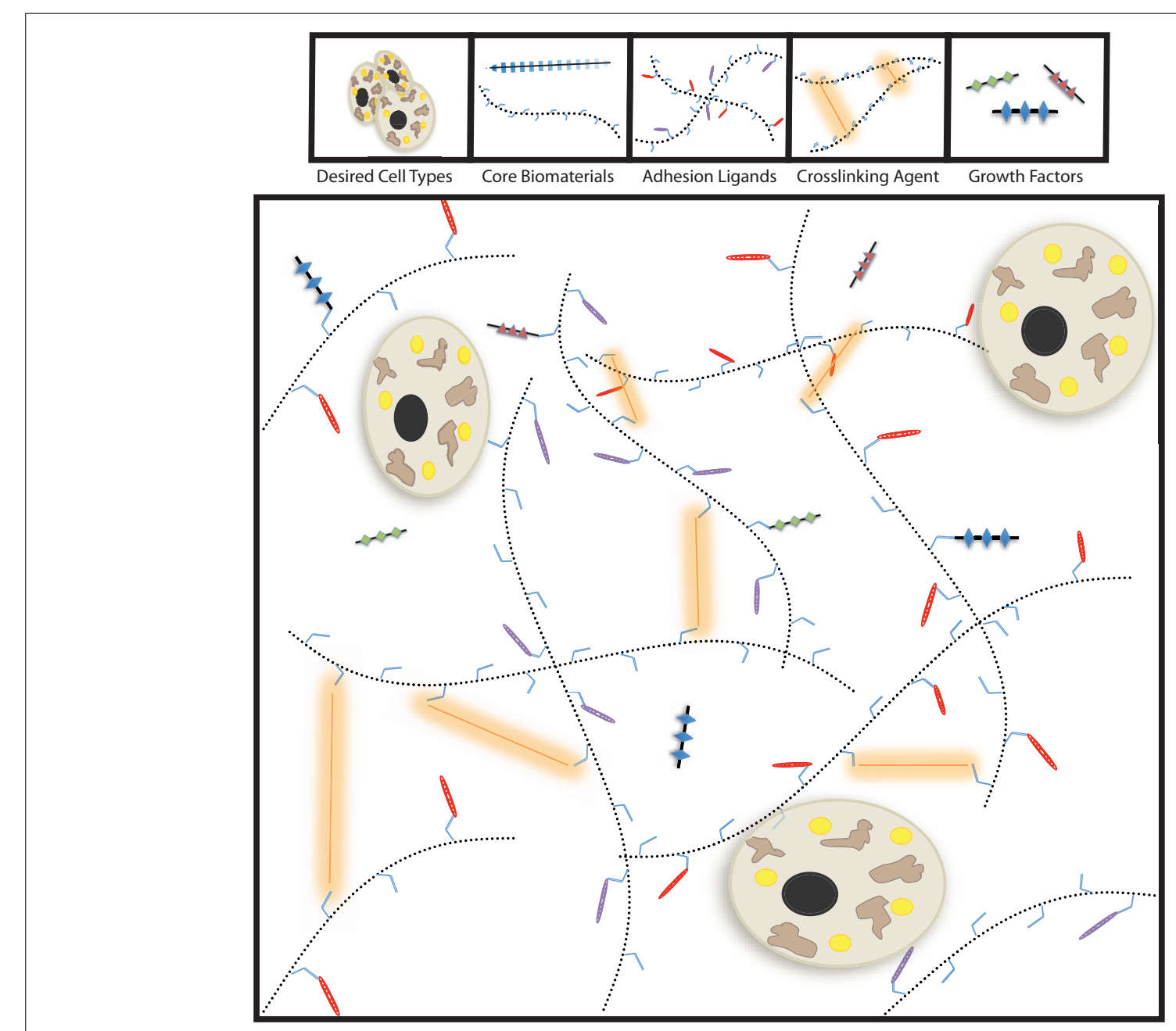

FIGURE 1 | Modular tissue-engineering. Here, we visually depict the five bioengineering variables discussed throughout this review. By tailoring the properties biochemical and physical properties of the biomaterial, synthetic tissues for therapeutic purposes can be successfully generated. 
biomaterial determines the method of deployment (injectablevs.-implantable), macrostructure, and the behavior of the cellular payload.

While many biocompatible materials have been proposed to engineer beige/brown-adipose tissue (93), HyA-based hydrogels show particular promise for the engineering of adipose tissue for therapeutic purposes $(94,95)$ and is the only material that has been successfully used to establish brown/beige fat implants in vivo (86). HyA is a naturally occurring glycosaminoglycan, consisting of $\beta$-1,4-D-glucuronic acid- $\beta$-1,3- $N$-acetyl-Dglucosamine, that is highly tractable for tissue-engineering for biomedical purposes $(94,95)$. Endogenous HyA is synthesized by hyaluronic acid synthase and extruded into the extracellular microenvironment, where it functions as an essential component of the native ECM and interacts with cell surface receptors such as CD44 or RHAMM (96). HyA is highly variable in length, spanning lengths up to $10 \mu \mathrm{M}$ and ranging from $100 \mathrm{kDa}$ to $8 \mathrm{mDa}$. Hyaluronic acid plays a pivotal role in ECM organization through its interactions with the other major components of the ECM (63).

HyA scaffolds enhance survival of autologous adipose stem-cell implants (97-100) and possibly promote adipose expansion (101). Not only are HyA-based hydrogels naturally occurring, biocompatible, modifiable, injectable, biodegradable, non-immunogenic, and anti-thrombogenic $(94,102)$, but also HyA has already been FDA approved for a number of clinical applications such as correction of facial lipoatrophy, wrinkle and scar removal, amelioration of osteoarthritic joint pain, dietary supplementation, ulcers, and cataract surgery. HyA has also showed clinical success for the temporary esthetic augmentation of lips, breasts, and buttocks (103), and achieved impressive results as a replacement of traditional dressings of epidermal burns and lesions (104). Importantly, utilizing HyA avoids fibrotic encapsulation of implants, a problem that has plagued the early literature of bioengineering (105). In general, avoiding encapsulation requires the use of nonimmunogenic materials and cells, biodegradable materials, nearly anisotropic physical properties to the surrounding tissues, and possibly growth factors to induce recruitment of host-derived cells into the implant. HyA has been shown to have significant effects on tissue remodeling and cell signaling, and is naturally degraded by hyaluronidase or oxidizing agents (106).

\section{CELLS FOR METABOLIC THERAPEUTICS}

Generation of bioengineered-BAT will rely on an easily accessible and ample source of progenitor cells. A key discovery in this regard came from the observation that UCP1+ adipocytes can be generated by certain WAT depots (107). These distinct adipocytes are described as beige/brite, and they express unique surface markers (3). While genetic factors play a major role in the ability to generate beige adipocytes $(108,109)$, the expansion of beige adipose mass has been linked to improved metabolic health. Therefore, the isolation of adipose-derived multipotent stem cells (MSCs) from undesirable WAT depots and subsequent reintroduction as autologous BAT shows therapeutic promise. One of the most abundant sources of preadipocytes is WAT, and the implantation of WAT-derived stem cells is an FDA accepted procedure (110).
The most common source of WAT-derived stem cells is the stromal vascular fraction (SVF), which contains $\mathrm{T}$ cells, $\mathrm{B}$ cells, mast cells, adipose tissue macrophages, and MSCs such as preadipocytes and endothelial progenitor cells. This cellular fraction can be further purified to enrich preadipocytes by selecting for cell surface markers such as Pref-1+, Lin-, CD29+, CD34+, Sca-1+, CD24+, CD45-, Mac1-, PDGFR $\alpha+(15,17$, 111). Additionally, preadipocyte sorting can be used to enrich for populations that are known to readily transdifferentiate into beige/brite fat such as CD137, TMEM26, ASC-1, PAT2, and P2RX5 (112). Alternatively, as stem-cell therapies become more accepted, induced pluripotent cells might be a suitable option since iPSC-derived brown adipocytes have also been generated and transplants of these cells show promising metabolic effects $(16,113)$.

While a purified population of preadipocytes or adipocytes may provide more conclusive insights for biological experiments, it may not be optimal for building a functional tissue. As previously mentioned, the immune system and vascular systems are essential for supporting the function and formation of beige adipose tissue and other SVF components could contribute to these tissue types. For example, macrophages and T cells have been shown to be an important part of beige/brown-adipose function and development $(33,51,114)$ and interactions between the adipocytes and the vascular niche may also be important for browning (115-118) particularly through cell-cell interactions, cytokines, and growth factors such as Il-33 (35) or VEGF-A (119). Thus, the use of multiple purified cell population or utilization of non-purified-SVF, as recently demonstrated for the generation of bioengineered-BAT (86), may offer distinct advantages.

\section{BIOMATERIAL OPTIMIZATION}

Degradation and remodeling ability of the synthetic ECM is just as important as the initial structure itself. If the synthetic tissues are not biodegradable through mechanisms that cells naturally use for movement and reorganization, integrating with the host will be jeopardized. Specifically, to facilitate effective remodeling and reorganization of the tissue by the immune and vascular systems, biodegradable and biologically interactive biomaterials should be utilized. The simplest way to imbue a biomaterial with biodegradability is to use MMP-sensitive crosslinking agents. Most of the available core materials can be easily modified to accommodate the current MMP-sensitive crosslinkers, which are short peptides containing an MMP-specific cleavage site (61, 120-122). Most of these core materials will be modified to facilitate efficient crosslinking by spontaneous aqueous phase reactions, such as the Michael addition where a thiol and acrylate form a thio-ether bond $(92,123)$. These types of biodegradable crosslinkers have been shown to be essential for the recruitment of host cells for the successful in vivo integration of biomaterial implants $(122,124)$.

Additionally, the elastic modulus of biomaterials has been shown to be highly instructive for the differentiation of MSCs into adipocytes (125-127). This mechanotransductive control of differentiation can be accomplished without applying direct physical forces to cells. By presenting a cell with an adhesion-promoting environment, matrix-associated adhesions form and produce an 
intrinsic mechanotransductive signal for the cell, as well as adjacent cells in the microenvironment. Therefore, a soft biomaterial optimized with specific adhesion-promoting ligands may be capable of inducing the same mechanotransductive signals as a much stiffer material. Numerous biological processes are affected by mechanical signals; notably, nuclear envelope plasticity and permeability $(128,129)$, splicing (130), and signal transduction (131). The prominent browning factor, BMP7, is known to alter cytoskeletal dynamics in adipocytes and other cell types, which supports the notion that physical cues may be important for bioengineered-BAT $(32,132-134)$. Interestingly, our group found that the storage modulus of WAT seems to differ from that of BAT (WAT $\sim 3 \mathrm{kPa}, \mathrm{BAT} \sim 4 \mathrm{kPa}$ ). How important this difference in modulus is for brown fat development and function remains to be explored more systematically.

Bioactive modifications, such as integrin-binding domains conjugated to hydrogels, have become commonplace to enhance the bioactivity of biomaterials $(61,90,91)$ and HyA-hydrogels augment integrin signaling (135). These materials provide some degree of ECM-mimicry without replicating the entire complexity of the native ECM. For example, alginate conjugated with RGD-containing ligands is supportive to cardiomyocytes and also promotes adipogenisis $(136,137)$. However, alginate's effects on adipogenisis may be due to the rounded morphology, shown to be strongly instructive to adipogenesis (72), cells undergo when encapsulated in alginate-based materials (138). Other peptidemodified hydrogels promote the formation of bone via collagen mimetic peptides (139). ADMSC-spheroids entrapped in Poly(ethylene glycol)-hydrogels have been proposed to form beige adipocytes in vitro (140) and have been modified to drive MSCs toward adipogenic or osteogenic fates (141). Interestingly, Vaicik et al. find UCP1-expression highest when the storage modulus of the hydrogel is BAT-equivalent.

Recent work by our laboratory to develop bioengineered-BAT with HyA-based biomaterials, differentiation promoting adhesion ligands, MMP-sensitive crosslinkers, and ADMSCs has produced a synthetic beige adipose tissue. The discovery of these bioactive modifications came from an effort to screen for ligands that preferentially promoted the attachment of UCP1+ adipocytes. Incidentally, it was discovered that some of these bioactive components, derived from laminin, directly enhanced UCP1-expression (86). The identified bioactive peptides were then conjugated to a HyA core material to promote browning. The assembly of the optimized hydrogel with adipocytes was termed beige adipose tissue-matrix-assisted cellular transplant (BAT-MACT), and was shown to successfully scaffold beige adipocytes for therapeutic purposes in animal models. What is particularly exciting about these HyA-hydrogels and MMPsensitive crosslinkers is that they are injectable, making this approach as non-invasive as possible. Due to HyA's viscoelastic properties, it can be easily mixed with the desired cell populations and just before implantation, mixed with the crosslinker. This allows for a short period of time where the cell-laden hydrogel is still a liquid and can be injected to the desired anatomical location with subsequent crosslinking to solidify a functional organoid.

The BAT-MACT implant system (Figure 2) has shown that implanted beige fat can have a nearly immediate effect on glucose homeostasis that persists during the duration of the implant's lifespan. Implanted beige adipose, similar to brown adipose, responds to cold stimulus by increasing lipid uptake an oxidation. The expansion of beige fat attenuates weight gain on a high-fat diet and induces a thermo-responsive metabolic augmentation to the recipient (86). Being that adipocytes derived from WAT sources are capable of sensing temperature independent neuronal signaling, it is not surprising that an implant of beige fat behaves this way. However, implanted classical brown adipose may not necessarily function in this manner, as the organ relies heavily on the sympathetic neuronal stimulation to induce the thermogenic program.

\section{FUTURE DIRECTIONS}

The first iteration of BAT-MACTs had an in vivo lifespan of approximately 3-4 weeks (86), which allows for well-controlled spatio-temporal applications but may be too short for singleapplication-based metabolic interventions. Further effort is needed to understand what would promote the maintenance of such a metabolically active depot for longer periods of time and if a microenvironment capable of promoting beige adipose

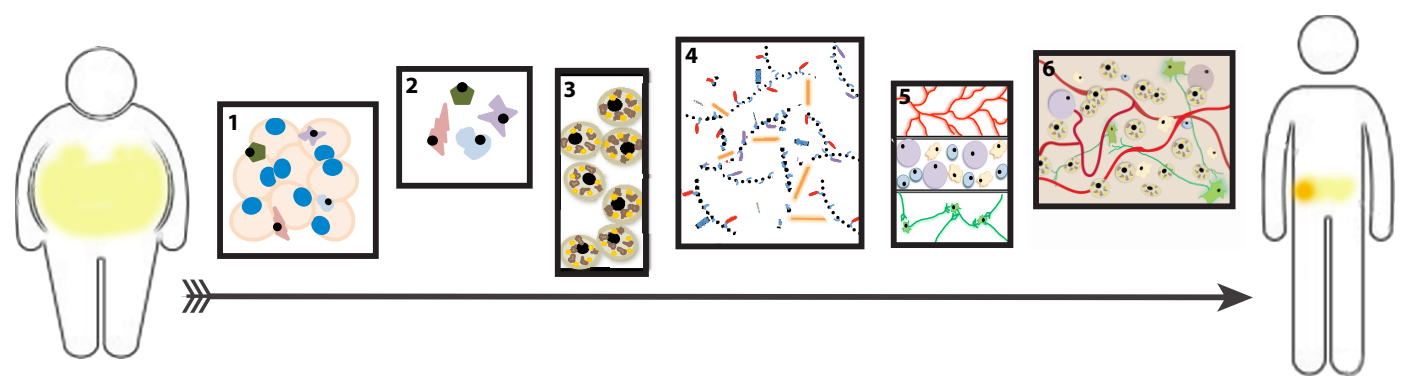

FIGURE 2 | Beige adipose tissue-matrix-assisted cellular transplant (BAT-MACT). The strategy used to expand beige adipose tissue for therapeutic purposes can be deconstructed into six stages: (1) Isolation of white adipose tissue (WAT) from patient. (2) Purification of stromal vascular fraction from the explanted WAT. (3) In vitro differentiation of SVF-derived preadipocytes toward the beige fat phenotype. (4) Suspension of beige adipocytes (SVF) into optimized hydrogel for implantation. (5) Post implantation, the hydrogel is biocompatible and degradable so that it is permissive to integrate the recipient's vascular, immune, and nervous systems. (6) The established beige adipose tissue functions as a metabolically active organ. If a sufficient increase of metabolic rate is achieved via BAT-MACT implantation, weight loss will occur. 
self-renewal could be created (71). The inclusion of modifications that enhance beige adipogenesis or metabolic activity, such as sequestered growth factors, small molecules, or mixed materials will certainly be pursued. Incorporating metabolic activators of beige adipocytes into the BAT-MACT system may be an essential step toward promoting weight loss and metabolic improvement in the face of thermoneutrality. At this stage, by using immobilized synthetic physical cues, the biomaterial component has a significantly lower risk of off target effects relative to a similarly functioning implant generated with secreted factors temporarily sequestered within the matrix. At its extreme, the implanted matrix could be endowed with sufficient biochemical and biophysical clues for the recruitment and directed differentiation of stem cells to allow for cell-free implants that are sufficient to establish beige adipose tissue. Such an acellular implant would be attractive as it could

\section{REFERENCES}

1. Liu Y, Vaughan CH, Bartness TJ, Yoneshiro T, Aita S, Matsushita M, et al. Recruited brown adipose tissue as an antiobesity agent in humans. J Neurosci (2013) 123:3404-8. doi:10.1172/JCI67803

2. Boss O, Farmer SR. Recruitment of brown adipose tissue as a therapy for obesity-associated diseases. Front Endocrinol (2012) 3:14. doi:10.3389/fendo. 2012.00014

3. Wu J, Bostrom P, Sparks LM, Ye L, Choi JH, Giang AH, et al. Beige adipocytes are a distinct type of thermogenic fat cell in mouse and human. Cell (2012) 150:366-76. doi:10.1016/j.cell.2012.05.016

4. Rosen ED, Spiegelman BM. What we talk about when we talk about fat. Cell (2014) 156:20-44. doi:10.1016/j.cell.2013.12.012

5. Nicholls DG, Locke RM. Thermogenic mechanisms in brown fat. Physiol Rev (1984) 64:1-64.

6. Fedorenko A, Lishko PV, Kirichok Y. Mechanism of fatty-acid-dependent UCP1 uncoupling in brown fat mitochondria. Cell (2012) 151:400-13. doi:10. 1016/j.cell.2012.09.010

7. Celi FS. Brown adipose tissue - when it pays to be inefficient. $N$ Engl J Med (2009) 360:1553-6. doi:10.1056/NEJMe0900466

8. Wang GX, Zhao XY, Lin JD. The brown fat secretome: metabolic functions beyond thermogenesis. Trends Endocrinol Metab (2015) 26:231-7. doi:10. 1016/j.tem.2015.03.002

9. Gunawardana SC, Piston DW. Insulin-independent reversal of type 1 diabetes in nonobese diabetic mice with brown adipose tissue transplant. Am J Physiol Endocrinol Metab (2015) 308:E1043-55. doi:10.1152/ajpendo.00570. 2014

10. Wang GX, Zhao XY, Meng ZX, Kern M, Dietrich A, Chen Z, et al. The brown fat-enriched secreted factor Nrg4 preserves metabolic homeostasis through attenuation of hepatic lipogenesis. Nat Med (2014) 20:1436-43. doi:10.1038/ nm.3713

11. Bredella MA, Gill CM, Rosen CJ, Klibanski A, Torriani M. Positive effects of brown adipose tissue on femoral bone structure. Bone (2014) 58:55-8. doi:10.1016/j.bone.2013.10.007

12. Nguyen AD, Lee NJ, Wee NK, Zhang L, Enriquez RF, Khor EC, et al. Uncoupling protein-1 is protective of bone mass under mild cold stress conditions. Bone (2015). doi:10.1016/j.bone.2015.05.037

13. Ohno H, Shinoda K, Spiegelman BM, Kajimura S. PPARgamma agonists induce a white-to-brown fat conversion through stabilization of PRDM16 protein. Cell Metab (2012) 15:395-404. doi:10.1016/j.cmet.2012.01.019

14. Elabd C, Chiellini C, Carmona M, Galitzky J, Cochet O, Petersen R, et al. Human multipotent adipose-derived stem cells differentiate into functional brown adipocytes. Stem Cells (2009) 27:2753-60. doi:10.1002/stem.200

15. Schulz TJ, Huang TL, Tran TT, Zhang H, Townsend KL, Shadrach JL, et al. Identification of inducible brown adipocyte progenitors residing in skeletal muscle and white fat. Proc Natl Acad Sci US A (2011) 108:143-8. doi:10.1073/ pnas. 1010929108 avoid many cost and health concerns associated with cellular implants.

Overall, extension of tissue-engineering principles to brown fat biology holds the promise of furthering both our mechanistic understanding of the factors required for brown/beige fat function and development, the rapid testing of hypothesis regarding the physiological impact of brown/beige tissue expansion, and ultimately novel treatment options for metabolic disorders.

\section{ACKNOWLEDGMENTS}

This work was supported in part by NIH grants R01DK101293 and R01DK089202, and the American Diabetes Association basic science award 1-14-BS-191 awarded to AS. We thank the Dr. Kevin Healy and Dr. Amit Jha for their contributions, and Jordan Tharp for assistance with figures and syntax.

16. Ahfeldt T, Schinzel RT, Lee YK, Hendrickson D, Kaplan A, Lum DH, et al Programming human pluripotent stem cells into white and brown adipocytes. Nat Cell Biol (2012) 14:209-19. doi:10.1038/ncb2411

17. Rodeheffer MS, Birsoy K, Friedman JM. Identification of white adipocyte progenitor cells in vivo. Cell (2008) 135:240-9. doi:10.1016/j.cell.2008.09.036

18. Edelstein ML, Abedi MR, Wixon J, Edelstein RM. Gene therapy clinical trials worldwide 1989-2004-an overview. J Gene Med (2004) 6:597-602. doi:10. 1002/jgm.619

19. Kajimura S, Seale P, Kubota K, Lunsford E, Frangioni JV, Gygi SP, et al. Initiation of myoblast to brown fat switch by a PRDM16-C/EBP-beta transcriptional complex. Nature (2009) 460:1154-8. doi:10.1038/nature08262

20. Liu X, Wang S, You Y, Meng M, Zheng Z, Dong M, et al. Brown adipose tissue transplantation reverses obesity in ob/ob mice. Endocrinology (2015) 156:2461-9. doi:10.1210/en.2014-1598

21. Gunawardana SC, Piston DW. Reversal of type 1 diabetes in mice by brown adipose tissue transplant. Diabetes (2012) 61:674-82. doi:10.2337/db11-0510

22. Stanford KI, Middelbeek RJ, Townsend KL, An D, Nygaard EB, Hitchcox $\mathrm{KM}$, et al. Brown adipose tissue regulates glucose homeostasis and insulin sensitivity. J Clin Invest (2013) 123:215-23. doi:10.1172/JCI62308

23. Komajda M, McMurray JJ, Beck-Nielsen H, Gomis R, Hanefeld M, Pocock SJ, et al. Heart failure events with rosiglitazone in type 2 diabetes: data from the record clinical trial. Eur Heart J (2010) 31:824-31. doi:10.1093/eurheartj/ ehp604

24. Moisan A, Lee YK, Zhang JD, Hudak CS, Meyer CA, Prummer M, et al. Whiteto-brown metabolic conversion of human adipocytes by JAK inhibition. Nat Cell Biol (2015) 17:57-67. doi:10.1038/ncb3075

25. Bostrom P, Wu J, Jedrychowski MP, Korde A, Ye L, Lo JC, et al. A PGC1-alphadependent myokine that drives brown-fat-like development of white fat and thermogenesis. Nature (2012) 481:463-8. doi:10.1038/nature10777

26. Jedrychowski MP, Wrann CD, Paulo JA, Gerber KK, Szpyt J, Robinson MM, et al. Detection and quantitation of circulating human irisin by tandem mass spectrometry. Cell Metab (2015) 22734-40. doi:10.1016/j.cmet.2015.08.001

27. Rao RR, Long JZ, White JP, Svensson KJ, Lou J, Lokurkar I, et al. Meteorin-like is a hormone that regulates immune-adipose interactions to increase beige fat thermogenesis. Cell (2014) 157:1279-91. doi:10.1016/j.cell.2014.03.065

28. Sellayah D, Sikder D. Orexin restores aging-related brown adipose tissue dysfunction in male mice. Endocrinology (2014) 155:485-501. doi:10.1210/en. 2013-1629

29. Than A, He HL, Chua SH, Xu D, Sun L, Leow MK, et al. Apelin enhances brown adipogenesis and browning of white adipocytes. J Biol Chem (2015) 290:14679-91. doi:10.1074/jbc.M115.643817

30. Fisher FM, Kleiner S, Douris N, Fox EC, Mepani RJ, Verdeguer F, et al. FGF21 regulates PGC-1alpha and browning of white adipose tissues in adaptive thermogenesis. Genes Dev (2012) 26:271-81. doi:10.1101/gad.177857.111

31. Tseng YH, Kokkotou E, Schulz TJ, Huang TL, Winnay JN, Taniguchi CM, et al. New role of bone morphogenetic protein 7 in brown adipogenesis and energy expenditure. Nature (2008) 454:1000-4. doi:10.1038/nature07221 
32. McDonald ME, Li C, Bian H, Smith BD, Layne MD, Farmer SR. Myocardinrelated transcription factor A regulates conversion of progenitors to beige adipocytes. Cell (2015) 160:105-18. doi:10.1016/j.cell.2014.12.005

33. Qiu Y, Nguyen KD, Odegaard JI, Cui X, Tian X, Locksley RM, et al. Eosinophils and type 2 cytokine signaling in macrophages orchestrate development of functional beige fat. Cell (2014) 157:1292-308. doi:10.1016/j.cell. 2014.03.066

34. Lee MW, Odegaard JI, Mukundan L, Qiu Y, Molofsky AB, Nussbaum JC, et al. Activated type 2 innate lymphoid cells regulate beige fat biogenesis. Cell (2015) 160:74-87. doi:10.1016/j.cell.2014.12.011

35. Brestoff JR, Kim BS, Saenz SA, Stine RR, Monticelli LA, Sonnenberg GF, et al. Group 2 innate lymphoid cells promote beiging of white adipose tissue and limit obesity. Nature (2015) 519:242-6. doi:10.1038/nature14115

36. Daquinag AC, Tseng C, Salameh A, Zhang Y, Amaya-Manzanares F, Dadbin A, et al. Depletion of white adipocyte progenitors induces beige adipocyte differentiation and suppresses obesity development. Cell Death Differ (2015) 22:351-63. doi:10.1038/cdd.2014.148

37. Himms-Hagen J, Cui J, Danforth E Jr, Taatjes DJ, Lang SS, Waters BL, et al. Effect of CL-316,243, a thermogenic beta 3-agonist, on energy balance and brown and white adipose tissues in rats. Am J Physiol (1994) 266:R1371-82.

38. Bonet ML, Oliver P, Palou A. Pharmacological and nutritional agents promoting browning of white adipose tissue. Biochim Biophys Acta (2013) 1831:969-85. doi:10.1016/j.bbalip.2012.12.002

39. Villarroya F, Vidal-Puig A. Beyond the sympathetic tone: the new brown fat activators. Cell Metab (2013) 17:638-43. doi:10.1016/j.cmet.2013.02.020

40. Jha AK, Mathur A, Svedlund FL, Ye J, Yeghiazarians Y, Healy KE. Molecular weight and concentration of heparin in hyaluronic acid-based matrices modulates growth factor retention kinetics and stem cell fate. J Control Release (2015) 209:308-16. doi:10.1016/j.jconrel.2015.04.034

41. Xu X, Jha AK, Duncan RL, Jia X. Heparin-decorated, hyaluronic acid-based hydrogel particles for the controlled release of bone morphogenetic protein 2 . Acta Biomater (2011) 7:3050-9. doi:10.1016/j.actbio.2011.04.018

42. Fan M, Ma Y, Zhang Z, Mao J, Tan H, Hu X. Biodegradable hyaluronic acid hydrogels to control release of dexamethasone through aqueous Diels-Alder chemistry for adipose tissue engineering. Mater Sci Eng C Mater Biol Appl (2015) 56:311-7. doi:10.1016/j.msec.2015.04.004

43. Bhakta G, Rai B, Lim ZX, Hui JH, Stein GS, van Wijnen AJ, et al. Hyaluronic acid-based hydrogels functionalized with heparin that support controlled release of bioactive BMP-2. Biomaterials (2012) 33:6113-22. doi:10.1016/j. biomaterials.2012.05.030

44. Yamamoto M, Takahashi Y, Tabata Y. Controlled release by biodegradable hydrogels enhances the ectopic bone formation of bone morphogenetic protein. Biomaterials (2003) 24:4375-83. doi:10.1016/S0142-9612(03)00337-5

45. Ishihara M, Fujita M, Obara K, Hattori H, Nakamura S, Nambu M, et al. Controlled releases of FGF-2 and paclitaxel from chitosan hydrogels and their subsequent effects on wound repair, angiogenesis, and tumor growth. Curr Drug Deliv (2006) 3:351-8. doi:10.2174/156720106778559047

46. Tae G, Kornfield JA, Hubbell JA. Sustained release of human growth hormone from in situ forming hydrogels using self-assembly of fluoroalkylended poly(ethylene glycol). Biomaterials (2005) 26:5259-66. doi:10.1016/j. biomaterials.2005.01.042

47. Schulz TJ, Huang P, Huang TL, Xue R, McDougall LE, Townsend KL, et al. Brown-fat paucity due to impaired BMP signalling induces compensatory browning of white fat. Nature (2013) 495:379-83. doi:10.1038/nature11943

48. Collins S. beta-adrenoceptor signaling networks in adipocytes for recruiting stored fat and energy expenditure. Front Endocrinol (2011) 2:102. doi:10.3389/ fendo.2011.00102

49. Ryu V, Garretson JT, Liu Y, Vaughan CH, Bartness TJ, Brown adipose tissue has sympathetic-sensory feedback circuits. J Neurosci (2015) 35:2181-90. doi: 10.1523/JNEUROSCI.3306-14.2015

50. Nguyen KD, Qiu Y, Cui X, Goh YP, Mwangi J, David T, et al. Alternatively activated macrophages produce catecholamines to sustain adaptive thermogenesis. Nature (2011) 480:104-8. doi:10.1038/nature10653

51. Wu D, Molofsky AB, Liang HE, Ricardo-Gonzalez RR, Jouihan HA, Bando $\mathrm{JK}$, et al. Eosinophils sustain adipose alternatively activated macrophages associated with glucose homeostasis. Science (2011) 332:243-7. doi:10.1126/ science. 1201475

52. Murano I, Barbatelli G, Giordano A, Cinti S. Noradrenergic parenchymal nerve fiber branching after cold acclimatisation correlates with brown adipocyte density in mouse adipose organ. J Anat (2009) 214:171-8. doi:10. 1111/j.1469-7580.2008.01001.x

53. Ye L, Wu J, Cohen P, Kazak L, Khandekar MJ, Jedrychowski MP, et al. Fat cells directly sense temperature to activate thermogenesis. Proc Natl Acad Sci U S A (2013) 110:12480-5. doi:10.1073/pnas.1310261110

54. Watanabe M, Houten SM, Mataki C, Christoffolete MA, Kim BW, Sato H, et al. Bile acids induce energy expenditure by promoting intracellular thyroid hormone activation. Nature (2006) 439:484-9. doi:10.1038/nature04330

55. Bordicchia M, Liu D, Amri EZ, Ailhaud G, Dessi-Fulgheri P, Zhang C, et al. Cardiac natriuretic peptides act via p38 MAPK to induce the brown fat thermogenic program in mouse and human adipocytes. J Clin Invest (2012) 122:1022-36. doi:10.1172/JCI59701

56. Obregon MJ. Adipose tissues and thyroid hormones. Front Physiol (2014) 5:479. doi:10.3389/fphys.2014.00479

57. Scadden DT. The stem-cell niche as an entity of action. Nature (2006) 441:1075-9. doi:10.1038/nature04957

58. Jones DL, Wagers AJ. No place like home: anatomy and function of the stem cell niche. Nat Rev Mol Cell Biol (2008) 9:11-21. doi:10.1038/nrm2319

59. Bissell MJ, Kenny PA, Radisky DC. Microenvironmental regulators of tissue structure and function also regulate tumor induction and progression: the role of extracellular matrix and its degrading enzymes. Cold Spring Harb Symp Quant Biol (2005) 70:343-56. doi:10.1101/sqb.2005.70.013

60. Saha K, Pollock JF, Schaffer DV, Healy KE. Designing synthetic materials to control stem cell phenotype. Curr Opin Chem Biol (2007) 11:381-7. doi:10. 1016/j.cbpa.2007.05.030

61. Lutolf MP, Hubbell JA. Synthetic biomaterials as instructive extracellular microenvironments for morphogenesis in tissue engineering. Nat Biotechnol (2005) 23:47-55. doi:10.1038/nbt1055

62. Bhat R, Bissell MJ. Of plasticity and specificity: dialectics of the microenvironment and macroenvironment and the organ phenotype. Wiley Interdiscip Rev Dev Biol (2014) 3:147-63. doi:10.1002/wdev.130

63. Mouw JK, Ou G, Weaver VM. Extracellular matrix assembly: a multiscale deconstruction. Nat Rev Mol Cell Biol (2014) 15:771-85. doi:10.1038/nrm3902

64. Wang Y, Botvinick EL, Zhao Y, Berns MW, Usami S, Tsien RY, et al. Visualizing the mechanical activation of src. Nature (2005) 434:1040-5. doi:10.1038/ nature 03469

65. Badylak SF, Taylor D, Uygun K. Whole-organ tissue engineering: decellularization and recellularization of three-dimensional matrix scaffolds. Annu Rev Biomed Eng (2011) 13:27-53. doi:10.1146/annurev-bioeng-071910124743

66. Young DA, Ibrahim DO, Hu D, Christman KL. Injectable hydrogel scaffold from decellularized human lipoaspirate. Acta Biomater (2011) 7:1040-9. doi: 10.1016/j.actbio.2010.09.035

67. Tibbitt MW, Anseth KS. Hydrogels as extracellular matrix mimics for 3D cell culture. Biotechnol Bioeng (2009) 103:655-63. doi:10.1002/bit.22361

68. Kim M, Lee JY, Jones CN, Revzin A, Tae G. Heparin-based hydrogel as a matrix for encapsulation and cultivation of primary hepatocytes. Biomaterials (2010) 31:3596-603. doi:10.1016/j.biomaterials.2010.01.068

69. Weber LM, Anseth KS. Hydrogel encapsulation environments functionalized with extracellular matrix interactions increase islet insulin secretion. Matrix Biol (2008) 27:667-73. doi:10.1016/j.matbio.2008.08.001

70. Friedland JC, Lakins JN, Kazanietz MG, Chernoff J, Boettiger D, Weaver VM. alpha6beta4 integrin activates Rac-dependent p21-activated kinase 1 to drive NF-kappaB-dependent resistance to apoptosis in 3D mammary acini. J Cell Sci (2007) 120:3700-12. doi:10.1242/jcs.03484

71. Lee ST, Yun JI, Jo YS, Mochizuki M, van der Vlies AJ, Kontos S, et al Engineering integrin signaling for promoting embryonic stem cell self-renewal in a precisely defined niche. Biomaterials (2010) 31:1219-26. doi:10.1016/j. biomaterials.2009.10.054

72. Spiegelman BM, Ginty CA. Fibronectin modulation of cell shape and lipogenic gene expression in 3T3-adipocytes. Cell (1983) 35:657-66. doi:10.1016/00928674(83)90098-3

73. Vaicik MK, Thyboll Kortesmaa J, Moverare-Skrtic S, Kortesmaa J, Soininen R, Bergstrom G, et al. Laminin alpha4 deficient mice exhibit decreased capacity for adipose tissue expansion and weight gain. PLoS One (2014) 9:e109854. doi:10.1371/journal.pone.0109854

74. Khan T, Muise ES, Iyengar P, Wang ZV, Chandalia M, Abate N, et al. Metabolic dysregulation and adipose tissue fibrosis: role of collagen VI. Mol Cell Biol (2009) 29:1575-91. doi:10.1128/MCB.01300-08 
75. Chun TH, Hotary KB, Sabeh F, Saltiel AR, Allen ED, Weiss SJ. A pericellular collagenase directs the 3-dimensional development of white adipose tissue. Cell (2006) 125:577-91. doi:10.1016/j.cell.2006.02.050

76. Gerlach JC, Lin YC, Brayfield CA, Minteer DM, Li H, Rubin JP, et al. Adipogenesis of human adipose-derived stem cells within three-dimensional hollow fiber-based bioreactors. Tissue Eng Part C Methods (2012) 18:54-61. doi:10. 1089/ten.TEC.2011.0216

77. Emont MP, Yu H, Jun H, Hong X, Maganti N, Stegemann JP, et al. Using a 3D culture system to differentiate visceral adipocytes in vitro. Endocrinology (2015): en20151567.

78. Francisco AT, Mancino RJ, Bowles RD, Brunger JM, Tainter DM, Chen YT, et al. Injectable laminin-functionalized hydrogel for nucleus pulposus regeneration. Biomaterials (2013) 34:7381-8. doi:10.1016/j.biomaterials.2013.06.038

79. Branco da Cunha C, Klumpers DD, Li WA, Koshy ST, Weaver JC, Chaudhuri $\mathrm{O}$, et al. Influence of the stiffness of three-dimensional alginate/collagenI interpenetrating networks on fibroblast biology. Biomaterials (2014) 35:8927-36. doi:10.1016/j.biomaterials.2014.06.047

80. Abberton KM, Bortolotto SK, Woods AA, Findlay M, Morrison WA, Thompson EW, et al. Myogel, a novel, basement membrane-rich, extracellular matrix derived from skeletal muscle, is highly adipogenic in vivo and in vitro. Cells Tissues Organs (2008) 188:347-58. doi:10.1159/000121575

81. Flynn LE. The use of decellularized adipose tissue to provide an inductive microenvironment for the adipogenic differentiation of human adipose-derived stem cells. Biomaterials (2010) 31:4715-24. doi:10.1016/j.biomaterials.2010.02.046

82. Xue R, Lynes MD, Dreyfuss JM, Shamsi F, Schulz TJ, Zhang H, et al. Clonal analyses and gene profiling identify genetic biomarkers of the thermogenic potential of human brown and white preadipocytes. Nat Med (2015) 21:760-8. doi:10.1038/nm.3881

83. Kasza I, Suh Y, Wollny D, Clark RJ, Roopra A, Colman RJ, et al. Syndecan1 is required to maintain intradermal fat and prevent cold stress. PLoS Genet (2014) 10:e1004514. doi:10.1371/journal.pgen.1004514

84. Liu J, DeYoung SM, Zhang M, Zhang M, Cheng A, Saltiel AR. Changes in integrin expression during adipocyte differentiation. Cell Metab (2005) 2:165-77. doi:10.1016/j.cmet.2005.08.006

85. Wu J, Cohen P, Spiegelman BM. Adaptive thermogenesis in adipocytes: is beige the new brown? Genes Dev (2013) 27:234-50. doi:10.1101/gad.211649. 112

86. Tharp KM, Jha AK, Kraiczy J, Yesian A, Karateev G, Sinisi R, et al. Matrix assisted transplantation of functional beige adipose tissue. Diabetes (2015). doi:10.2337/db15-0728

87. Khalifeh-Soltani A, McKleroy W, Sakuma S, Cheung YY, Tharp K, Qiu Y, et al. Mfge8 promotes obesity by mediating the uptake of dietary fats and serum fatty acids. Nat Med (2014) 20:175-83. doi:10.1038/nm.3450

88. Tapias LF, Ott HC. Decellularized scaffolds as a platform for bioengineered organs. Curr Opin Organ Transplant (2014) 19:145-52. doi:10.1097/MOT. 0000000000000051

89. Silva FJ, Holt DJ, Vargas V, Yockman J, Boudina S, Atkinson D, et al. Metabolically active human brown adipose tissue derived stem cells. Stem Cells (2014) 32:572-81. doi:10.1002/stem.1595

90. Griffith LG. Emerging design principles in biomaterials and scaffolds for tissue engineering. Ann N Y Acad Sci (2002) 961:83-95. doi:10.1111/j.1749-6632. 2002.tb03056.x

91. Rice JJ, Martino MM, De Laporte L, Tortelli F, Briquez PS, Hubbell JA. Engineering the regenerative microenvironment with biomaterials. Adv Healthc Mater (2013) 2:57-71. doi:10.1002/adhm.201200197

92. Lutolf MP, Raeber GP, Zisch AH, Tirelli N, Hubbell JA. Cell-responsive synthetic hydrogels. Adv Mater Deerfield (2003) 15:888-92. doi:10.1002/adma. 200304621

93. Unser AM, Tian Y, Xie Y. Opportunities and challenges in three-dimensional brown adipogenesis of stem cells. Biotechnol Adv (2015) 33:962-79. doi:10. 1016/j.biotechadv.2015.07.005

94. Xu X, Jha AK, Harrington DA, Farach-Carson MC, Jia X. Hyaluronic acidbased hydrogels: from a natural polysaccharide to complex networks. Soft Matter (2012) 8:3280-94. doi:10.1039/c2sm06463d

95. Burdick JA, Prestwich GD. Hyaluronic acid hydrogels for biomedical applications. Adv Mater (2011) 23:H41-56. doi:10.1002/adma.201003963

96. Yang B, Yang BL, Savani RC, Turley EA. Identification of a common hyaluronan binding motif in the hyaluronan binding proteins RHAMM, CD44 and link protein. EMBO J (1994) 13:286-96.
97. Stillaert FB, Di Bartolo C, Hunt JA, Rhodes NP, Tognana E, Monstrey S, et al. Human clinical experience with adipose precursor cells seeded on hyaluronic acid-based spongy scaffolds. Biomaterials (2008) 29:3953-9. doi:10.1016/j. biomaterials.2008.06.005

98. Piccinno MS, Veronesi E, Loschi P, Pignatti M, Murgia A, Grisendi G, et al. Adipose stromal/stem cells assist fat transplantation reducing necrosis and increasing graft performance. Apoptosis (2013) 18:1274-89. doi:10.1007/ s10495-013-0878-7

99. Kim YM, Oh SH, Choi JS, Lee S, Ra JC, Lee JH, et al. Adipose-derived stem cell-containing hyaluronic acid/alginate hydrogel improves vocal fold wound healing. Laryngoscope (2014) 124:E64-72. doi:10.1002/lary.24405

100. Moreno A, Martinez A, Olmedillas S, Bello S, de Miguel F. Hyaluronic acid effect on adipose-derived stem cells. Biological in vitro evaluation. Rev Esp Cir Ortop Traumatol (2015) 59:215-21. doi:10.1016/j.recot.2014.10.004

101. Huang SH, Lin YN, Lee SS, Chai CY, Chang HW, Lin TM, et al. New adipose tissue formation by human adipose-derived stem cells with hyaluronic acid gel in immunodeficient mice. Int J Med Sci (2015) 12:154-62. doi:10.7150/ijms. 9964

102. Prestwich GD. Engineering a clinically-useful matrix for cell therapy. Organogenesis (2008) 4:42-7. doi:10.4161/org.6152

103. De Meyere B, Mir-Mir S, Penas J, Camenisch CC, Heden P. Stabilized hyaluronic acid gel for volume restoration and contouring of the buttocks: 24month efficacy and safety. Aesthetic Plast Surg (2014) 38:404-12. doi:10.1007/ s00266-013-0251-9

104. Voigt J, Driver VR. Hyaluronic acid derivatives and their healing effect on burns, epithelial surgical wounds, and chronic wounds: a systematic review and meta-analysis of randomized controlled trials. Wound Repair Regen (2012) 20:317-31. doi:10.1111/j.1524-475X.2012.00777.x

105. Anderson JM, Rodriguez A, Chang DT. Foreign body reaction to biomaterials Semin Immunol (2008) 20:86-100. doi:10.1016/j.smim.2007.11.004

106. Burdick JA, Chung C, Jia X, Randolph MA, Langer R. Controlled degradation and mechanical behavior of photopolymerized hyaluronic acid networks. Biomacromolecules (2005) 6:386-91. doi:10.1021/bm049508a

107. Cousin B, Cinti S, Morroni M, Raimbault S, Ricquier D, Penicaud L, et al. Occurrence of brown adipocytes in rat white adipose tissue: molecular and morphological characterization. J Cell Sci (1992) 103(Pt 4):931-42.

108. Xue B, Rim JS, Hogan JC, Coulter AA, Koza RA, Kozak LP. Genetic variability affects the development of brown adipocytes in white fat but not in interscapular brown fat. J Lipid Res (2007) 48:41-51. doi:10.1194/jlr.M600287JLR200

109. Kozak LP. The genetics of brown adipocyte induction in white fat depots. Front Endocrinol (2011) 2:64. doi:10.3389/fendo.2011.00064

110. Yoshimura K, Suga H, Eto H. Adipose-derived stem/progenitor cells: roles in adipose tissue remodeling and potential use for soft tissue augmentation. Regen Med (2009) 4:265-73. doi:10.2217/17460751.4.2.265

111. Lee YH, Petkova AP, Mottillo EP, Granneman JG. In vivo identification of bipotential adipocyte progenitors recruited by beta3-adrenoceptor activation and high-fat feeding. Cell Metab (2012) 15:480-91. doi:10.1016/j.cmet.2012. 03.009

112. Ussar S, Lee KY, Dankel SN, Boucher J, Haering MF, Kleinridders A, et al. ASC-1, PAT2, and P2RX5 are cell surface markers for white, beige, and brown adipocytes. Sci Transl Med (2014) 6:247ra103. doi:10.1126/scitranslmed. 3008490

113. Nishio M, Yoneshiro T, Nakahara M, Suzuki S, Saeki K, Hasegawa M, et al. Production of functional classical brown adipocytes from human pluripotent stem cells using specific hemopoietin cocktail without gene transfer. Cell Metab (2012) 16:394-406. doi:10.1016/j.cmet.2012.08.001

114. Medrikova D, Sijmonsma TP, Sowodniok K, Richards DM, Delacher M, Sticht C, et al. Brown adipose tissue harbors a distinct sub-population of regulatory T cells. PLoS One (2015) 10:e0118534. doi:10.1371/journal.pone.0118534

115. Tang W, Zeve D, Suh JM, Bosnakovski D, Kyba M, Hammer RE, et al. White fat progenitor cells reside in the adipose vasculature. Science (2008) 322:583-6. doi:10.1126/science.1156232

116. Nolan DJ, Ginsberg M, Israely E, Palikuqi B, Poulos MG, James D, et al. Molecular signatures of tissue-specific microvascular endothelial cell heterogeneity in organ maintenance and regeneration. Dev Cell (2013) 26:204-19. doi:10.1016/j.devcel.2013.06.017

117. Butler JM, Kobayashi H, Rafii S. Instructive role of the vascular niche in promoting tumour growth and tissue repair by angiocrine factors. Nat Rev Cancer (2010) 10:138-46. doi:10.1038/nrc2791 
118. Bi P, Shan T, Liu W, Yue F, Yang X, Liang XR, et al. Inhibition of notch signaling promotes browning of white adipose tissue and ameliorates obesity. Nat Med (2014) 20:911-8. doi:10.1038/nm.3615

119. Sun K, Wernstedt Asterholm I, Kusminski CM, Bueno AC, Wang ZV, Pollard JW, et al. Dichotomous effects of VEGF-A on adipose tissue dysfunction. Proc Natl Acad Sci U S A (2012) 109:5874-9. doi:10.1073/pnas.1200447109

120. Schultz KM, Kyburz KA, Anseth KS. Measuring dynamic cell-material interactions and remodeling during 3D human mesenchymal stem cell migration in hydrogels. Proc Natl Acad Sci U S A (2015) 112:E3757-64. doi:10.1073/pnas. 1511304112

121. Wall ST, Yeh CC, Tu RY, Mann MJ, Healy KE. Biomimetic matrices for myocardial stabilization and stem cell transplantation. J Biomed Mater Res A (2010) 95:1055-66. doi:10.1002/jbm.a.32904

122. Kim S, Chung EH, Gilbert M, Healy KE. Synthetic MMP-13 degradable ECMs based on poly( $\mathrm{N}$-isopropylacrylamide-co-acrylic acid) semi-interpenetrating polymer networks. I. Degradation and cell migration. J Biomed Mater Res A (2005) 75:73-88. doi:10.1002/jbm.a.30375

123. Mather BD, Viswanathan K, Miller KM, Long TE. Michael addition reactions in macromolecular design for emerging technologies. Prog Polym Sci (2006) 31:487-531. doi:10.1016/j.progpolymsci.2006.03.001

124. Lutolf MP, Lauer-Fields JL, Schmoekel HG, Metters AT, Weber FE, Fields GB, et al. Synthetic matrix metalloproteinase-sensitive hydrogels for the conduction of tissue regeneration: engineering cell-invasion characteristics. Proc Natl Acad Sci U S A (2003) 100:5413-8. doi:10.1073/pnas.0737381100

125. Engler AJ, Sen S, Sweeney HL, Discher DE. Matrix elasticity directs stem cell lineage specification. Cell (2006) 126:677-89. doi:10.1016/j.cell.2006.06.044

126. Guvendiren M, Burdick JA. Stiffening hydrogels to probe short- and longterm cellular responses to dynamic mechanics. Nat Commun (2012) 3:792. doi:10.1038/ncomms1792

127. Young DA, Choi YS, Engler AJ, Christman KL. Stimulation of adipogenesis of adult adipose-derived stem cells using substrates that mimic the stiffness of adipose tissue. Biomaterials (2013) 34:8581-8. doi:10.1016/j.biomaterials. 2013.07.103

128. Kumar A, Mazzanti M, Mistrik M, Kosar M, Beznoussenko GV, Mironov AA, et al. ATR mediates a checkpoint at the nuclear envelope in response to mechanical stress. Cell (2014) 158:633-46. doi:10.1016/j.cell.2014.05.046

129. Shivashankar GV. Mechanosignaling to the cell nucleus and gene regulation. Annu Rev Biophys (2011) 40:361-78. doi:10.1146/annurev-biophys-042910155319

130. Jakkaraju S, Zhe X, Pan D, Choudhury R, Schuger L. TIPs are tensionresponsive proteins involved in myogenic versus adipogenic differentiation. Dev Cell (2005) 9:39-49. doi:10.1016/j.devcel.2005.04.015

131. Hughes-Fulford M. Signal transduction and mechanical stress. Sci STKE (2004) 2004:RE12. doi:10.1126/stke.2492004re12
132. Vinall RL, Lo SH, Reddi AH. Regulation of articular chondrocyte phenotype by bone morphogenetic protein 7, interleukin 1, and cellular context is dependent on the cytoskeleton. Exp Cell Res (2002) 272:32-44. doi:10.1006/excr.2001. 5395

133. Fuchshofer R, Stephan DA, Russell P, Tamm ER. Gene expression profiling of TGFbeta2- and/or BMP7-treated trabecular meshwork cells: identification of Smad7 as a critical inhibitor of TGF-beta2 signaling. Exp Eye Res (2009) 88:1020-32. doi:10.1016/j.exer.2009.01.002

134. Konstantinidis G, Moustakas A, Stournaras C. Regulation of myosin light chain function by BMP signaling controls actin cytoskeleton remodeling. Cell Physiol Biochem (2011) 28:1031-44. doi:10.1159/000335790

135. Chopra A, Murray ME, Byfield FJ, Mendez MG, Halleluyan R, Restle DJ, et al. Augmentation of integrin-mediated mechanotransduction by hyaluronic acid. Biomaterials (2014) 35:71-82. doi:10.1016/j.biomaterials.2013.09.066

136. Shachar M, Tsur-Gang O, Dvir T, Leor J, Cohen S. The effect of immobilized RGD peptide in alginate scaffolds on cardiac tissue engineering. Acta Biomater (2011) 7:152-62. doi:10.1016/j.actbio.2010.07.034

137. Kang SW, Cha BH, Park H, Park KS, Lee KY, Lee SH. The effect of conjugating RGD into 3D alginate hydrogels on adipogenic differentiation of human adipose-derived stromal cells. Macromol Biosci (2011) 11:673-9. doi:10.1002/ mabi.201000479

138. Lee KY, Mooney DJ. Hydrogels for tissue engineering. Chem Rev (2001) 101:1869-79. doi:10.1021/cr000108x

139. Mehta M, Madl CM, Lee S, Duda GN, Mooney DJ. The collagen I mimetic peptide DGEA enhances an osteogenic phenotype in mesenchymal stem cells when presented from cell-encapsulating hydrogels. J Biomed Mater Res A (2015) 103:3516-25. doi:10.1002/jbm.a.35497

140. Vaicik MK, Morse M, Blagajcevic A, Rios J, Larson JC, Yang F, et al. Hydrogelbased engineering of beige adipose tissue. J Mater Chem B (2015) 3:7903-11. doi:10.1039/C5TB00952A

141. Benoit DS, Schwartz MP, Durney AR, Anseth KS. Small functional groups for controlled differentiation of hydrogel-encapsulated human mesenchymal stem cells. Nat Mater (2008) 7:816-23. doi:10.1038/nmat2269

Conflict of Interest Statement: The authors declare that the research was conducted in the absence of any commercial or financial relationships that could be construed as a potential conflict of interest.

Copyright $(2) 2015$ Tharp and Stahl. This is an open-access article distributed under the terms of the Creative Commons Attribution License (CC BY). The use, distribution or reproduction in other forums is permitted, provided the original author(s) or licensor are credited and that the original publication in this journal is cited, in accordance with accepted academic practice. No use, distribution or reproduction is permitted which does not comply with these terms. 